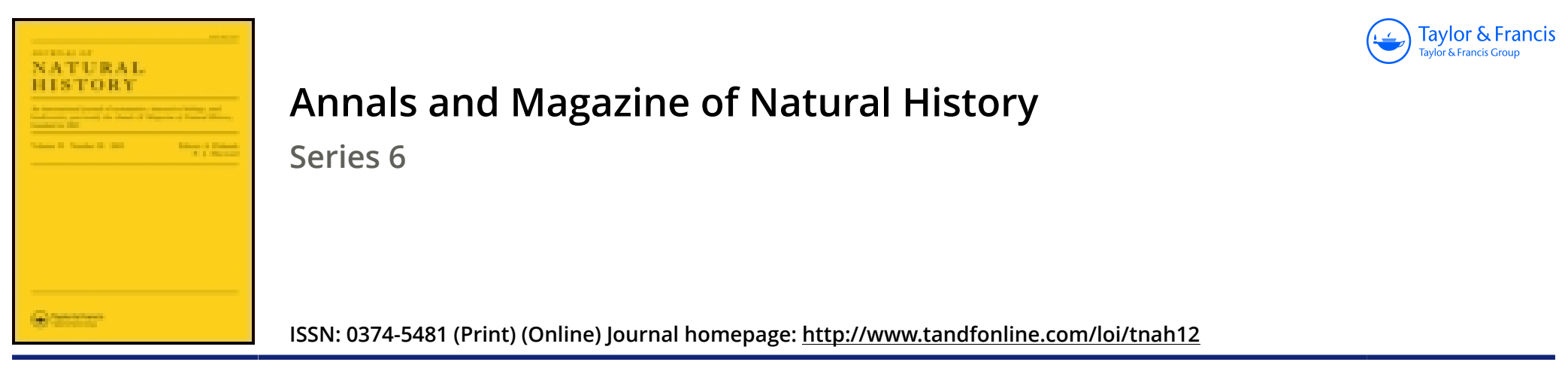

\title{
IV.-On the genus Hypocala, a group of Noctuid moths
}

\author{
Arthur G. Butler F.L.S. F.Z.S.
}

To cite this article: Arthur G. Butler F.L.S. F.Z.S. (1892) IV.-On the genus Hypocala, a group of Noctuid moths, Annals and Magazine of Natural History, 10:55, 17-22, DOI: $10.1080 / 00222939208677370$

To link to this article: http://dx.doi.org/10.1080/00222939208677370

Published online: 02 Oct 2009.

Submit your article to this journal ${ }^{\pi}$

Џll Article views: 7

Q View related articles 두 
IV.-On the Genus Hypocala, a Group of Noctuid Moths. By Arthur G. Butler, F.L.S., F.Z.S., \&c.

IN the seventh volume of the 'Illustrations of Typical Lepidoptera Heterocera,' p. 76, I pointed out that the species of Ilypocala were trimorphic: this fact has led to so much confusion that a revision of the species has become a necessity. When once understood the forms of this genus are easily recognizable; the primaries on the upper surface vary considerably, but always in the same way; the secondaries and the under surface are constant in pattern in all the modifications of each species.

M. Guenée, who would never identify an insect from a rough figure, and yet rarely failed to describe every differing form in his possession, however bad the specimen might be, multiplied species unnecessarily.

Whether from their rarity or the difficulty of capturing these moths, I do not know, but they seem to come to hand chiefly as individual specimens and at long intervals, so that of several of the species only one, or at most two, of the forms which represent the variations of each type have hitherto found their way to us. Mr. Hocking seems to have been more successful in collecting Hypocala than most men. In his Dharmsala series we obtained all three forms of H. subsatura in the following proportions:-five of the typical form, four of the variety $H$. aspersa, and four of the variety $H$. limbata (the last-mentioned having, up to that time, been unrecorded).

In the following synopsis I propose to define the species hitherto described with their varieties. In order to avoid repetition in diagnosing the forms it may be premised that any good figure (such, for instance, as that given by M. Guenee, 'Noctuélites,' iii. pl. xiii. fig. 7) will represent the general characteristics in the pattern of the genus, if one allows for the more blurred uniform character of the primaries in the variety which I regard as typical, and the sharply defined but melanic character of the form which I have characterized as var. $b$. The secondaries are always ochreous and black above, and the under surface is usually pale ochreous, more or less marked with blackish and greyish.

The under surface gives the best characters for the differentiation of the species, and therefore I shall make my primary divisions on points of difference to be seen on that surface of the wings.

Ann.\& Mag. N. Hist. Ser. 6. Vol. x. 
A. Wings below pale ochreous; primaries with black discal patch divided by a band of the ground-colour ; secondaries with a black spot at end of cell and an oblique bar from anal angle to second median branch.

a. Black patch on primaries broadly divided, leaving only a narrow bar of black on its inner edge; spot of secondaries small and anal bar very narrow

H. clarissima.

$b$. Black patch barely divided by a narrow central bar; spot of secondaries elongated, anal bar broad .........H. violacea.

B. Wings below ochreous, greyish on costal and apical areas; primaries with a black discal patch enclosing an ovate transverse ochreous spot; secondaries with a black spot at end of cell; an irregular, partly marginal, black band from anal angle to just above lower radial vein, its outer edge interrupted by two spots, that nearest anal angle small and angular .......

H. florens.

C. Wings below ochreous, irrorated with purplish grey on costal and apical areas; primaries with the usual black discal patch represented by two rather broad, abbreviated, parallel, oblique bars; secondaries with a conspicuous spot at end of cell; the usual blackish band narrow, irregularly zigzag, broadly expanded at its upper extremity and extending from close to anal angle to second subcostal branch

H. deflorata.

D. Primaries below almost as in $\mathbf{B}$, but the black patch bounded below by the first median branch; discocellular spot quadrate; the blackish band zigzag, alternately narrow and broad, extending from near anal angle almost to the first subcostal branch.

a. Secondaries above chiefly ochreous, much more so than in any other described species

H. guttiventris.

E. Wings below with cell of primaries and inner two thirds of secondaries bright ochreous, rewainder of ground-colour paler; apical area greyish, the latter and costal border striated with brown atoms; primaries with two broad black bars, converging at their lower extremities.

a. Secondaries with a short, oblique, narrow, irregular black bar on the discocellulars; outer border blackish, shading into brown towards costa, becoming paler on margin towards apex and interrupted towards anal angle by an unequal, angular, ochreous, marginal patch towards

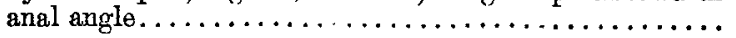

H. andremona.

b. Primaries with the black bars broader, almost touching at lower extremities; the inner bar emitting a broad grey streak below the cell almost to the base; secondaries with the blackish portion of the outer border broader, emitting a black denticle towards the lower extremity of the discocellular bar, interrupted towards the anal angle by two separate marginal ocbreous spots.

H. subsatura. 
F. Wings below with costal and apical areas smoky grey, the black or blackish bars on the primaries almost united at lower extremity, the outer one diffused; the black or blackish external belt of secondaries broad, externally and apically diffused, excepting towards anal angle, where it is interrupted by a marginal clavate streak or spot.

a. Size of $H$. andremona, secondaries above with pale ochreous markings; external black border decreasing towards anal angle, deeply excavated just above the

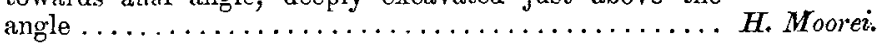

b. The largest known species; below deep ochreous, the inner black bar of primaries with an external denticle; discocellular bar of secondaries broad and externally angular; hind wings above with deep ochreous markings ; external black border very broad before anal angle, moderately excavated just above the angle ...........

H. australia:

c. Similar to $b$, but with the whole under surface and the upper surface of the secondaries smoky, obscuring the markings, which are also paler and less defined in themselves

H. velans.

Of the above species, all of which are represented in the Museum collection, we possess all three varieties of two species only. For the convenience of students of the group I give the following arrangement of the varieties, classified according to the colouring of the primaries, whether uniform, variegated, or bicoloured :-

Uniform.

H. subsatura.

$H$. defiorata.

$H$. guttiventris.

$H$. andremona.

$H$. australice.

$H$. velans.

H. florens (Mab.).

H. clarissine .

$H$. violacea.
Variegated.

$H$. aspersa.

$H$. plumicornis.

H. lativitta.

$H$. Pierreti.

H. Moorei.

H. velans.

H. florents (Mab.).
Bicoloured.

H. limbata. H. rostrata.

H. florens (in B. M).

It seems probable that the first and second forms (which appear to be inconstant and merge into each other) are one brood, and the very distinct-looking third form another; that they represent in fact either spring and autumn or dry- and wet-season forms of the species. Whether this is so or not can only be proved by breeding, and it is worth the consideration of those who have the opportunity of obtaining the eggis or larvæ. 


\section{List of Species.}

\section{Hypocala subsatura.}

‡. Hypocala subsatura, Guenée, Noct. iii. p. 75 . n. 1419 (1852).

Var. a. Hypocala aspersa, Butler, P. Z. S. 1883, p. 164.

Var. b. Hypocaln limbata, Butler, Ill. Typ. Lep. Het. vii. p. 76, pl. cxxxi. fig. 13 (1889).

Dharmsala, Solun, and Canara. B. M.

\section{Hypocala deflorata.}

Noctua deforata, Fabricius, Naturf. p. 190, pl. ii. figs. 6, 7.

Var. a. Hypocala plumicornis, Guenée, Noct. iii. p. 75. n. 1420 (1852).

Hypocala efforescens, Guenée, l. c. p. 77. n. 1423 (1852).

Hypocala angulipalpis, Guenee, l. c. n. 1424 (1852).

Var. b. Noctua rostrata, Fabricius, Naturf. p. 197, pl. iv. fig. 4.

Madras, N. India, Dharmsala, Nilgiris, Kilima-njaro, Natal. B. M.

It is a common form of superstition amongst naturalists to assume that examples of the same species cannot occur both in India and Africa; M. Guenée was evidently strongly imbued with this opinion. The difference represented by the following words alone serves to separnte $H$. plumicornis and efflorescens : of the first it is said, "Un seul 'o, qui m'a été envoyé comme venant de la Cafrerie : mais cette provenance me laisse quelques doutes." Why? Because in other respects it closely resembled $H$. efflorescens, of which we read, "Silhet. Coll. Gn. Un of." As for $H$. angulipalpis, it was based upon a single dwarfed and much rubbed example.

\section{Hypocala guttiventris.}

Hypocala guttiventris, Walker, Lep. Het. xiii. p. 1176. n. 10 (1857). Hypocala tryphanina, Felder, Reise der Nov., Lep. iv. pl. cxii. fig. 20. Var. a. Hypocala lativitta, Walker, Lep. Het. Suppl. iit. p. 929 (1865). Moreton Bay and S.E. Australia. Type B. M.

\section{Hypocala andremona.}

Phalena-Noctua andremona, Cramer, Pap. Exot. iv. p. 132, pl. ccclviii. figs. C, $\mathrm{D}$ (1782).

Hypocala filicornis, Guenée, Noct. iii. p. 76. n. 1421, pl. xiii. fig. 7 (1852).

Var. a. Hypocala Pierreti, Guenee, l. c. p. 77. n. 1425 (1852).

Honduras, Amazons, São Paulo. B. M. 


\section{Hypocala MFoorei, sp. n.}

Var. a. Hypocala efforescens, var., Walker, Lep. Het. xiii. p. 1175. n. 8 (1852); Moore, Lep. Ceylon, iii. p. 126, pl. clx. figs. 5, 5 a.

Ceylon, Canara, Old Calabar. B. M.

This is quite distinct from $H$. efflorescens of Guenée.

Hypocala australice, sp. n.

Secondaries above most like those of $H$. subsatura, but deeper and brighter in colour, with marginal ochreous spot.

Australia. B. M.

Represents H. velans in Australia.

Hypocala velans.

Var. a. Hypocala velans, Walker, Lep. Het. xiii. p. 1177. n. 11 (1852).

Hawaiian Islands. Type B. M.

Hypocala florens.

Hypocala florens, Nabille, Trans. Soc. Ent. Fr. 1879, p. 324.

Madagascar. B. M.

M. Mabille describes several forms of this species; our specimen belongs to the variety with pale inner border to the primaries (var. $b$ of this monograph).

\section{Hypocala clarissima, sp. n.}

Differs from $H$. violacea above in the greater width of its ochreous markings.

Ceylon. B. M.

This and $H$. violacea both belong to the typical form of the genus in which the primaries are of a uniform character; both agree in having these wings of a lilacine rufous-brown colour.

\section{Hypocala violacea.}

Hypocala violacea, Butler, Trans. Ent. Soc. 1879 , p. 0. Cachar and Burmah. Type B. M.

Hypocala tenuis, Walk., from Sierra Leone, does not appea: to me to belong to the genus; but the description is too poor to enable me to decide the point.

Hypocala biarcuata, Walk., from Canara, is either a species 
of Audea (Catocalidx) or belongs to a genus allied to Audea; it has nothing to do with Hypocala.

Hypocala lativitta, Moore (said to be nearest to H. biarcu$a t a)$, is almost certainly a species of Audea; the porrect beak-like palpi of Hypocala are not shown in the figure, which, on the other hand, gives the impression of their being formed as in Audea.

\section{V.-Description of a new Species of Acomys. By Oldfield Thomas.}

AMONG a small collection of zoological specimens from Mombasa recently presented to the National Collection by Mr. D. J. Wilson, of the British East Africa Company's service, there occurs a specimen of a small spiny mouse clearly representing a new species. A second specimen of the same form has also been received direct from the Company, but the exact locality of this individual is unknown.

I propose to call the species

\section{Acomys Wilsoni, sp. n.}

Most nearly allied to $A$. russatus, Wagn., but distinguished from that, as from every other member of the genus, by its very much smaller size, and especially by its much shorter feet. General colour orange-rufous, grizzled with black, the black predominating on the head and nape. Under surface white. Ears small, rounded, laid forward they just reach to the posterior canthus of the eye. Feet short and broad; palms and soles naked, the pads well defined. Tail short, slender, very finely haired, almost naked; darker above, whiter below; rings of scales about seventeen to the centimetre.

Measurements of the type (an adult female in alcohol) :-

Head and body 80 millim.; tail 48 (extreme tip wanting, 55 in the other specimen); hind foot $12 \cdot 2$; heel to front of last foot-pad $5 \cdot 8$; ear, above crown, $8 \cdot 4$.

Hab. Mombasa. Coll. D. J. Wilson.

The other species of the genus are all much larger than $D$. Wilsoni, with hind feet measuring from 16 to 19 millim., a difference in size so great as to preclude all necessity for a detailed comparison of the new form with them.

It is with much pleasure that I have named this little species in honour of its discoverer, to whose enthusiasm the British Museum is indebted for many rare and interesting specimens. 